\title{
Influence of Si Addition on Reduction Behavior of Fe Oxide on Mn-Added Steel Sheet
}

\author{
Satoshi MAEDA, ${ }^{*}$ Yusuke FUSHIWAKI and Yasunobu NAGATAKI \\ JFE Steel Corporation, 1, Kawasaki-cho, Chuo-ku, Chiba, 260-0835 Japan. \\ (Received on August 27, 2019; accepted on October 8, 2019; originally published in Tetsu-to-Hagané, \\ Vol. 104, 2018, No. 9, pp. 509-516
}

\begin{abstract}
The influence of the Si content of $\mathrm{Mn}$-added steel sheets on the reduction behavior of Fe oxide during oxidation followed by annealing in a $10 \% \mathrm{H}_{2}$ atmosphere simulating the Fe oxidation-reduction process was investigated using 5.2 mass \% Mn steel with 0, 0.2 and 0.5 mass\% added Si. Reduction of the $\mathrm{Fe}$ oxide was more rapid in the $0.2 \%$ and $0.5 \%$ mass $\%$ Si steels than in the 0 mass $\%$ Si steel. Because Si addition increased the proportion of hematite $\left(\mathrm{Fe}_{2} \mathrm{O}_{3}\right)$ and decreased that of wustite $(\mathrm{FeO})$ in the Fe oxide, the difference in reduction speed due to $\mathrm{Si}$ addition is thought to depend on the composition of the $\mathrm{Fe}$ oxide. It was suggested that reduction from hematite to magnetite $\left(\mathrm{Fe}_{3} \mathrm{O}_{4}\right)$ induces larger lattice defects in the Fe oxide, resulting in a higher diffusion rate of $\mathrm{O}$.
\end{abstract}

KEY WORDS: Fe oxidation-reduction process; Fe oxide composition; hematite; magnetite; lattice defect.

\section{Introduction}

Reduction of auto body weight has become an important issue in recent years due to environmental concerns, and use of high strength steel is seen as an effective approach to weight saving. ${ }^{1,2)}$ At the same time, use of galvanized high strength steel has also increased in response to more stringent corrosion protection requirements. $\mathrm{Si}$ and $\mathrm{Mn}$ are frequently added to galvanized high strength steels to acquire the requisite balance of high strength and good elongation, which is necessary for press forming. But those elements form surface oxides during recrystallization annealing, which have adverse effect on the $\mathrm{Zn}$ coating property. ${ }^{3,4)}$

To prevent surface oxidation during recrystallization annealing, the $\mathrm{Fe}$ oxidation-reduction process is used in the continuous galvanizing line $(\mathrm{CGL}){ }^{5)}$ In this process, the steel sheet is heated in an oxidizing atmosphere for Fe before recrystallization annealing to oxidize the steel surface. The resulting Fe oxide on the sheet surface is then reduced during recrystallization annealing, and the surface is covered with reduced Fe, which limits diffusion of easilyoxidizing elements. Easily-oxidizing elements near the steel surface can also be oxidized by oxygen and water vapor supplied by reduction of the $\mathrm{Fe}$ oxide; this phenomenon is termed internal oxidation. These effects prevent surface oxidation and improve surface quality.

Fe oxidation of Si- and Mn-added steels has been studied extensively. It is well known that $\mathrm{Si}$ suppresses Fe oxidation by segregating and forming an oxide between the Fe oxide layer and the steel surface, while Mn has little effect

* Corresponding author: E-mail: sa-maeda@jfe-steel.co.jp DOI: https://doi.org/10.2355/isijinternational.ISIJINT-2019-531 on Fe oxidation because Mn dissolves in the Fe oxide ${ }^{6,7)}$ However, few reports have examined the influence of Si and $\mathrm{Mn}$ on reduction of the Fe oxide, and most of that research is related to the smelting process, ${ }^{8,9)}$ which is characterized by high temperatures exceeding $800^{\circ} \mathrm{C}$ and a long reduction time of more than $1 \mathrm{~h}$. Since those conditions are far from those of the $\mathrm{Fe}$ oxidation-reduction process in continuous annealing, in this paper, we investigated the effect of $\mathrm{Si}$ addition on the behavior of $\mathrm{Fe}$ oxidation and $\mathrm{Fe}$ oxide reduction under the typical time and temperature conditions of the Fe oxidation-reduction process. The specimen materials were 5 mass $\%$ Mn steel with $0,0.2$ and 0.5 mass $\%$ added $\mathrm{Si}$, which has been reported as a next-generation high elongation steel. ${ }^{10-12)}$

\section{Experimental Procedure}

Samples of 5.2 mass \% Mn-added steel containing 0, 0.2 or 0.5 mass $\% \mathrm{Si}$ were prepared in the laboratory. In the following, these steels are denoted $0 \% \mathrm{Si}$ steel, $0.2 \% \mathrm{Si}$ steel and $0.5 \% \mathrm{Si}$ steel, respectively. The steels were cold-rolled to a thickness of $1.0 \mathrm{~mm}$ and cut to dimensions of $70 \mathrm{~mm} \times$ $180 \mathrm{~mm}$, degreased with ethanol, electrolytically degreased with 3 mass $\% \mathrm{NaOHaq}$ and then pickled with 5 mass $\% \mathrm{HCl}$ to clean the sample surface.

Oxidation treatment and the subsequent reduction annealing were conducted in an infrared furnace with a controlled atmosphere. First, Fe oxidation was performed using the heat cycle shown in Fig. 1(a). The samples were heated at a rate of $10^{\circ} \mathrm{C} \cdot \mathrm{s}^{-1}$, held at 0 or $20 \mathrm{~s}$ at each temperature (oxidation temperature), and then cooled to room temperature with $\mathrm{N}_{2}$ gas. Basically, the atmosphere used in oxidation treatment was $0.2 \mathrm{vol} \% \mathrm{O}_{2}-\mathrm{N}_{2}$ with a $20^{\circ} \mathrm{C}$ D.P., but in one 
particular experiment, the $\mathrm{O}_{2}$ concentration was changed from $0.1 \mathrm{vol} \%$ to $1.0 \mathrm{vol} \%$ to control the composition of the Fe oxide. In the following, the samples prepared by oxidation treatment are called Fe oxidation steels.

Next, the heat cycle used in reduction annealing is shown in Fig. 1(b). The samples were heated to $600^{\circ} \mathrm{C}$ at $13^{\circ} \mathrm{C} \cdot \mathrm{s}^{-1}$, followed by heating to the specified temperature (reduction temperature) in $100 \mathrm{~s}$. The samples were then cooled to room temperature with $\mathrm{N}_{2}$ gas. The atmosphere used in reduction annealing was $15 \mathrm{vol} \% \mathrm{H}_{2}-\mathrm{N}_{2}$ with a $-35^{\circ} \mathrm{C}$ D.P. Short-time reduction annealing was also conducted using the heat cycle shown in Fig. 2 to investigate the initial reduction behavior. The samples which were subjected to reduction annealing are called annealing steels. The following analyses were carried out with the Fe oxidation steels and annealing steels.

Conventionally, $\mathrm{Fe}$ oxidation and $\mathrm{Fe}$ oxide reduction were quantified by measuring mass change. ${ }^{8)}$ However, measurement of mass change was not possible in this experiment, as the thickness of the Fe oxide was less than $1 \mu \mathrm{m}$, which was considered too small to measure. Therefore, as an alternative method, we investigated the change in the oxygen content in the steel. The oxygen content was measured by infrared absorption, ${ }^{13)}$ and the amounts of $\mathrm{Fe}$ oxidation and $\mathrm{Fe}$ oxide reduction were quantified by the increase and decrease of oxygen. The increase of oxygen per $1 \mathrm{~m}^{2}$ during $\mathrm{Fe}$ oxidation treatment was defined as the

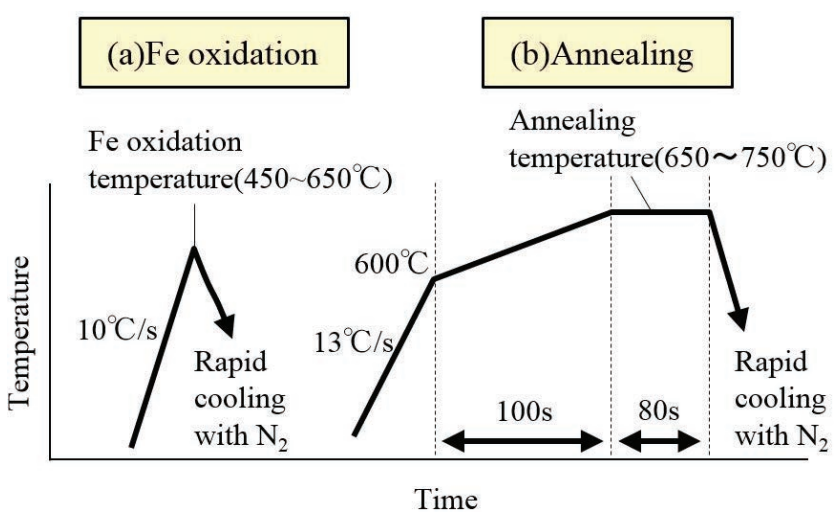

Fig. 1. Heat pattern of (a) Fe oxidation and (b) annealing. (Online version in color.)

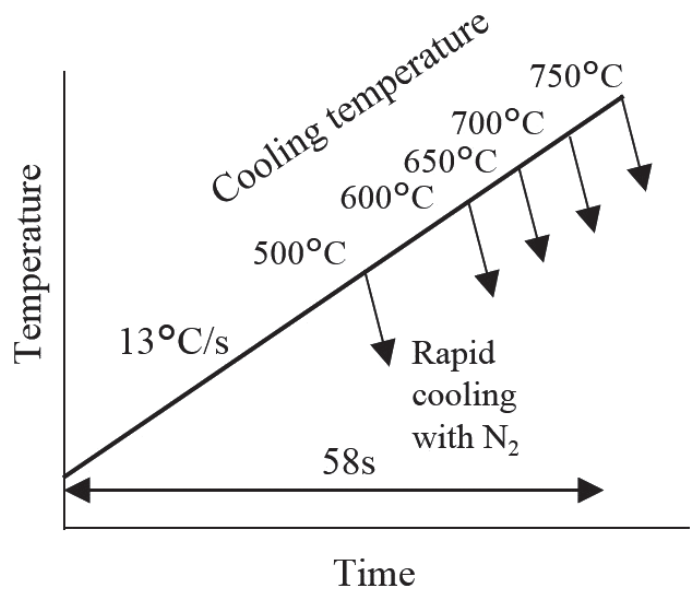

Fig. 2. Heat pattern of annealing for investigating Initial reduction behavior. oxidation amount, and decrease during reduction annealing was defined as the reduction amount.

The composition of the Fe oxide was identified by X-ray diffraction (XRD). Characteristic X-rays of $\mathrm{Cu} \mathrm{K}$ (alpha) were used, and the angle of X-ray incidence was $2.0^{\circ}$. The amount of $\mathrm{Fe}$ oxide was evaluated by the integrated intensity of $\alpha-\mathrm{Fe}_{2} \mathrm{O}_{3}(104), \mathrm{Fe}_{3} \mathrm{O}_{4}(220)$ and $\mathrm{FeO}(200)$.

The surface and cross section of the Fe oxide were observed with a scanning electron microscope (SEM) at an accelerating voltage of $1-5 \mathrm{kV}$. Back scattered electron (BSE) images were used to distinguish metal from oxides. The cross section of the Fe oxide was also observed with a transmission electron microscope (TEM), and energy dispersive X-ray spectrometry (EDX) was used to measure its composition.

\section{Results}

\subsection{Effect of Si Addition on Fe Oxidation Behavior}

The effect of $\mathrm{Si}$ addition on Fe oxidation behavior was observed as a preliminary investigation, before examining the reduction of the Fe oxide. Figure 3 shows the influence of the oxidation temperature and $\mathrm{Si}$ addition on the oxidation amount. The oxidation amount decreased with increasing $\mathrm{Si}$ addition. Figure 4 shows the XRD results for each Si-added steel when oxidized at $600^{\circ} \mathrm{C}$. Here, the

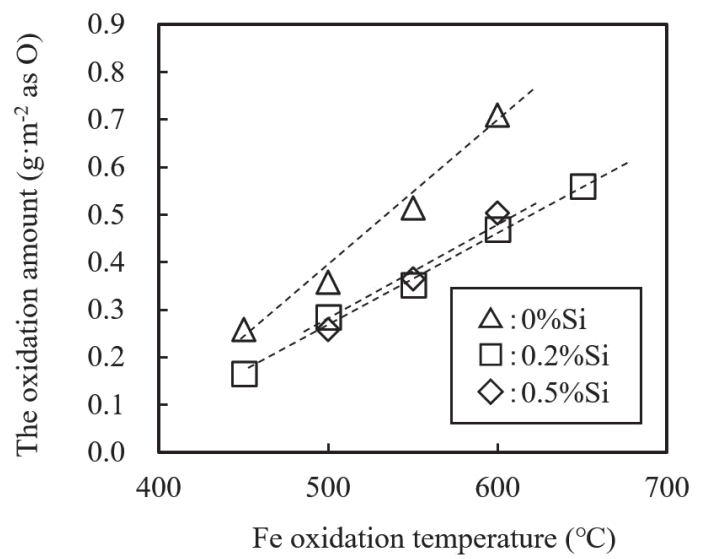

Fig. 3. Influence of $\mathrm{Fe}$ oxidation temperature and $\mathrm{Si}$ addition on the amount of Fe oxide.

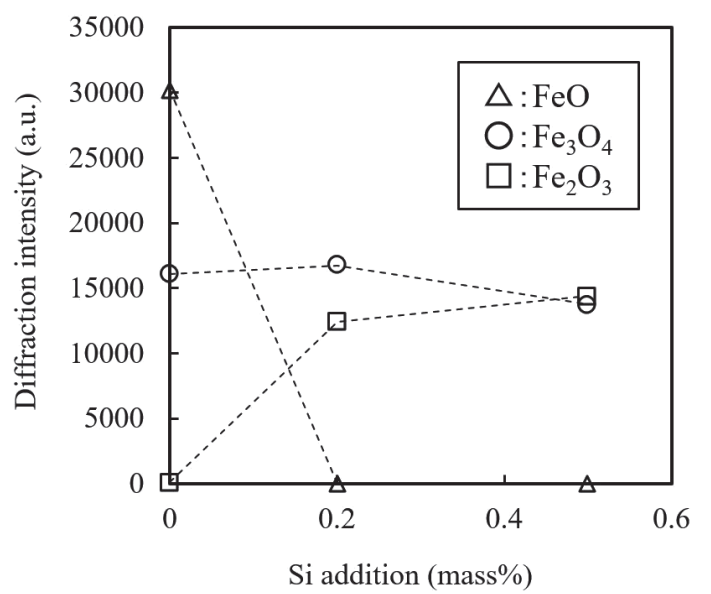

Fig. 4. Relationship between $\mathrm{Si}$ addition and diffraction intensity of Fe oxide (Fe oxidation temperature: $600^{\circ} \mathrm{C}$ ). 
$\mathrm{FeO}$ intensity decreased and the $\mathrm{Fe}_{2} \mathrm{O}_{3}$ intensity increased with increasing Si addition. This tendency was substantially the same at the other oxidation temperatures. Figure 5 shows cross-sectional TEM images of the surface of each $\mathrm{Si}$-added steel when oxidized at $500^{\circ} \mathrm{C}$ and $550^{\circ} \mathrm{C}$. A thin $30 \mathrm{~nm}$ layer was observed between the Fe substrate and the Fe oxide in the $0.2 \%$ and $0.5 \% \mathrm{Si}$ steels. Figure 6 shows the results of an EDX line analysis across the boundary of the $\mathrm{Fe}$ substrate and $\mathrm{Fe}$ oxide in the $0 \%$ and $0.5 \% \mathrm{Si}$ steels.
The $\mathrm{Si}$ and $\mathrm{O}$ intensities were high near the thin layer in the $0.5 \% \mathrm{Si}$ steel.

\subsection{Effect of Si Addition on Reduction Behavior of $\mathbf{F e}$ Oxide}

To investigate the reduction behavior of the Fe oxide, reduction annealing was conducted with each $\mathrm{Si}$ steel. The oxidation amount of all samples was adjusted to be about $0.4 \mathrm{~g} \cdot \mathrm{m}^{-2}$ as O. Figure 7 shows the cross-sectional BSE

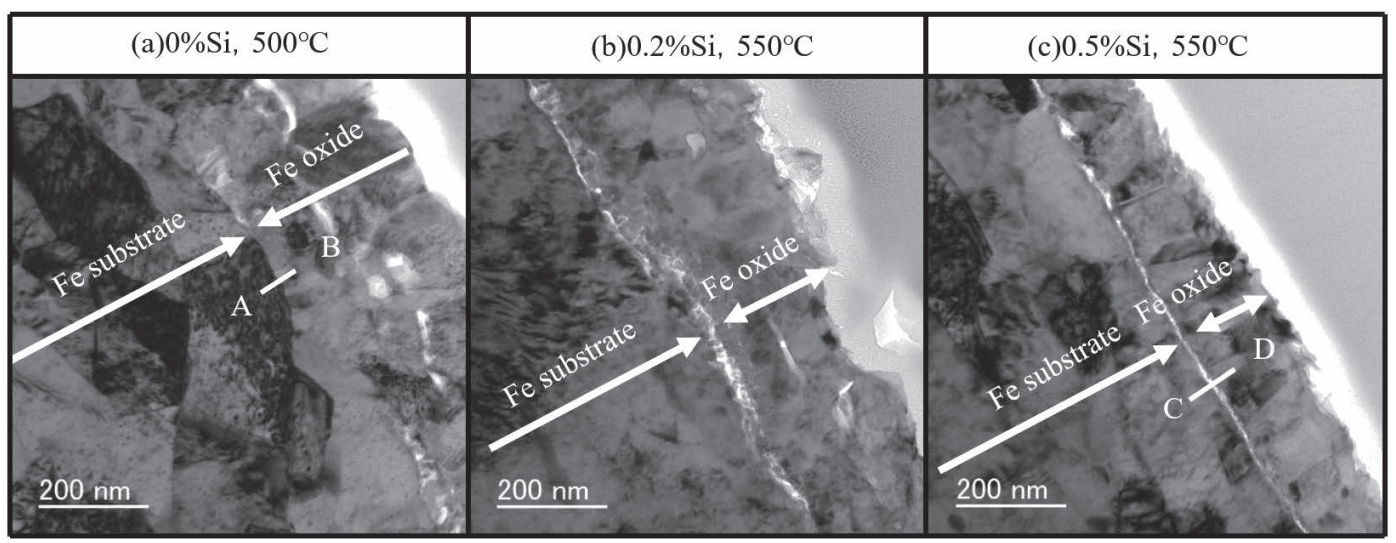

Fig. 5. TEM images of the cross section of each Si-added steel oxidized at $500^{\circ} \mathrm{C}$ and $550^{\circ} \mathrm{C}$.

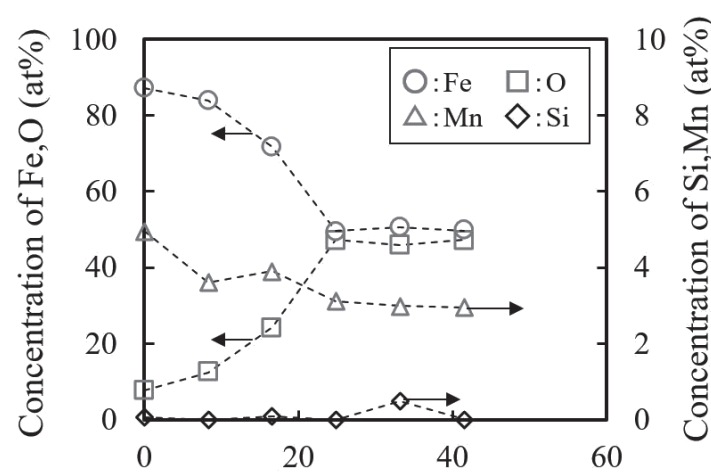

Distance from A (nm)

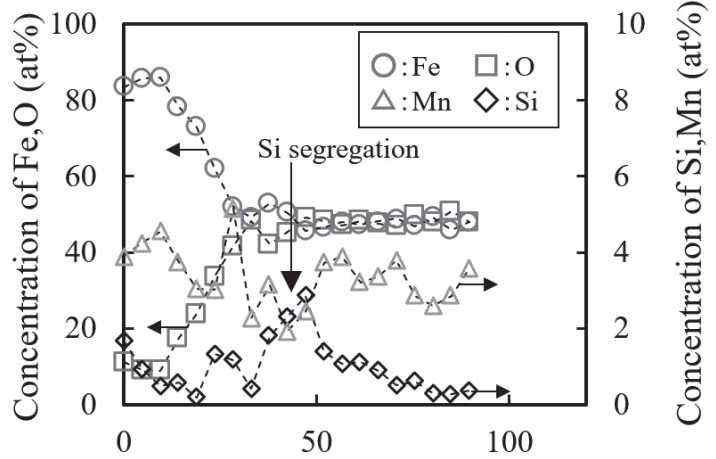

Distance from C (nm)

Fig. 6. EDX line analysis of $\mathrm{A}-\mathrm{B}(0 \% \mathrm{Si})$ and $\mathrm{C}-\mathrm{D}(0.5 \% \mathrm{Si})$ in Fig. 5.

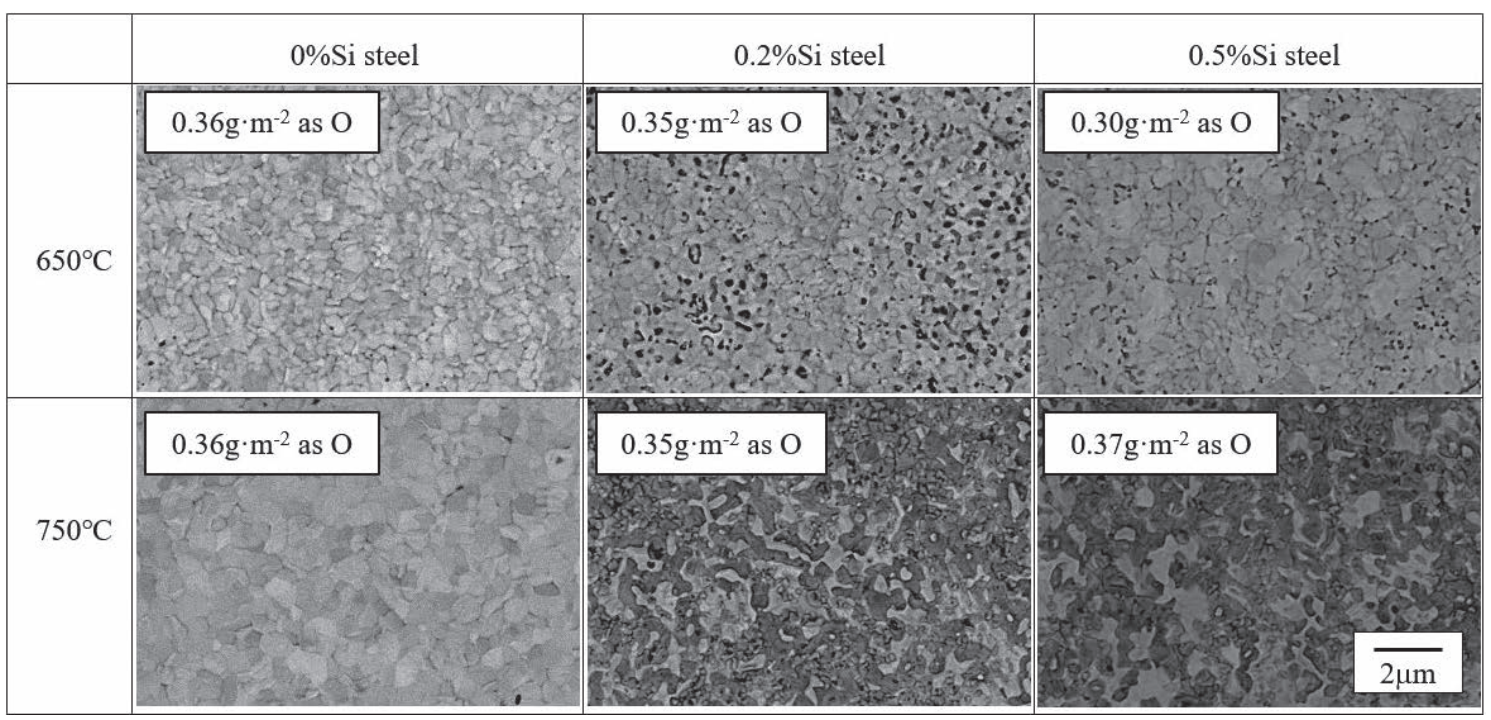

Fig. 7. BSE images of the surface of each Si-added steel annealed at $650{ }^{\circ} \mathrm{C}$ and $750^{\circ} \mathrm{C}$ with approximately $0.4 \mathrm{~g} \cdot \mathrm{m}^{-2}$ as $\mathrm{O} F$ oxide. 
images of the annealing steels. At the annealing temperature of $650{ }^{\circ} \mathrm{C}$, numerous pores with a size of about 0.2 $\mu \mathrm{m} \phi$ were observed in the $0.2 \%$ and $0.5 \% \mathrm{Si}$ steels. Figure 8 shows the cross-sectional BSE images and EDX results of the annealing steels. In the $0 \% \mathrm{Si}$ steel, a thin outermost layer of reduced Fe with a thickness of $0.05-0.1 \mu \mathrm{m}$ and a thicker underlying layer of Fe oxide were observed after annealing at $650^{\circ} \mathrm{C}$, and internal oxides comprising mainly Mn were observed after annealing at $750^{\circ} \mathrm{C}$. In contrast, the Fe oxide layer was not observed in the $0.2 \%$ and $0.5 \%$ $\mathrm{Si}$ steels, and internal oxides, mainly of $\mathrm{Mn}$ and $\mathrm{Si}$, were observed at a deeper level than in the $0 \% \mathrm{Si}$ steel. Figure 9 shows the reduction amount of each $\mathrm{Si}$ steel. The reduction amounts of the $0.2 \%$ and $0.5 \% \mathrm{Si}$ steels were 2.5 times larger than that of the $0 \% \mathrm{Si}$ steel, providing a clear indication that $\mathrm{Si}$ addition accelerates reduction of the $\mathrm{Fe}$ oxide.

Since $\mathrm{Si}$ addition caused a pronounced change in the reduction behavior after reduction annealing, the initial reduction behavior was investigated with the heat pattern shown in Fig. 2. The $0 \% \mathrm{Si}$ steel oxidized at $550^{\circ} \mathrm{C}$ and the $0.5 \% \mathrm{Si}$ steel oxidized in $600^{\circ} \mathrm{C}$ were used in this experiment. Figure 10 shows surface BSE images after heating at each temperature (cooling temperature) and quenching with $\mathrm{N}_{2}$. At the $500^{\circ} \mathrm{C}$ cooling temperature, the surface was covered with Fe oxide. However, as the temperature was increased, the Fe oxide was partially reduced $600^{\circ} \mathrm{C}$, and the surface was covered with reduced $\mathrm{Fe}$ at $750^{\circ} \mathrm{C}$. Although the surface oxide reduction speed differed slightly in the $0 \%$ and $0.5 \%$ Si steels, porosity was observed only in the $0.5 \% \mathrm{Si}$ steel in the initial stage of reduction, and the number of pores increased as $\mathrm{Fe}$ oxide reduction proceeded. Figure 11 shows the cross-sectional BSE images and EDX results around a pore in a $0.5 \% \mathrm{Si}$ steel sample prepared with the $600^{\circ} \mathrm{C}$ cooling temperature.
In this figure, considerable reduction of the Fe oxide has occurred around the pore.

To investigate the effect of the Fe oxide composition on reduction behavior, reduction annealing was conducted using oxidation steels having different Fe oxide compositions. The Fe oxide composition was controlled by changing the $\mathrm{O}_{2}$ concentration in the atmosphere. Figure 12 shows the effect of the $\mathrm{O}_{2}$ concentration on the Fe oxide composition of the $0.5 \% \mathrm{Si}$ steel for the oxidation temperature of $600^{\circ} \mathrm{C}$ and holding time of $20 \mathrm{~s}$. With increasing $\mathrm{O}_{2}, \mathrm{Fe}_{3} \mathrm{O}_{4}$ decreased and $\mathrm{Fe}_{2} \mathrm{O}_{3}$ increased. Figure 13 shows the reduction amounts of these samples. In particular, it should be noted that the reduction amount was larger in the steel with the large composition of $\mathrm{Fe}_{2} \mathrm{O}_{3}$, even though the oxidation amount was substantially the same in both materials.

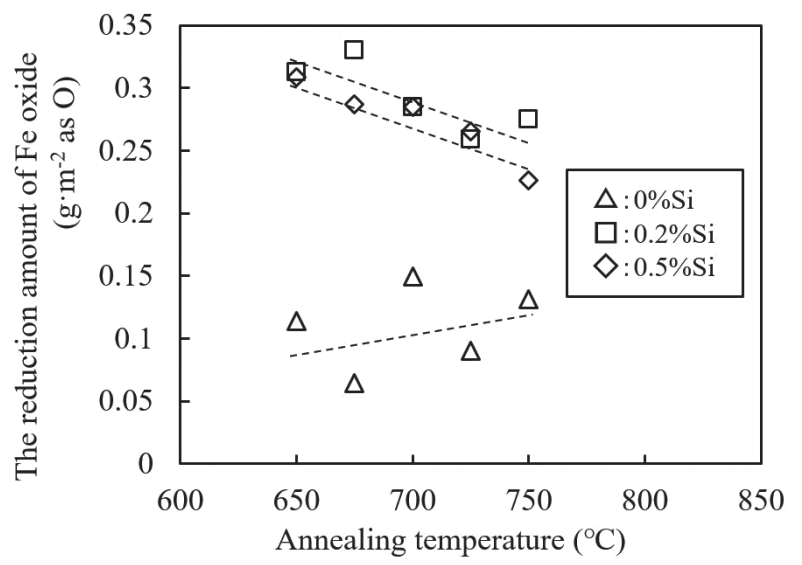

Fig. 9. Effect of $\mathrm{Si}$ addition on decrease in amount of oxygen through annealing.

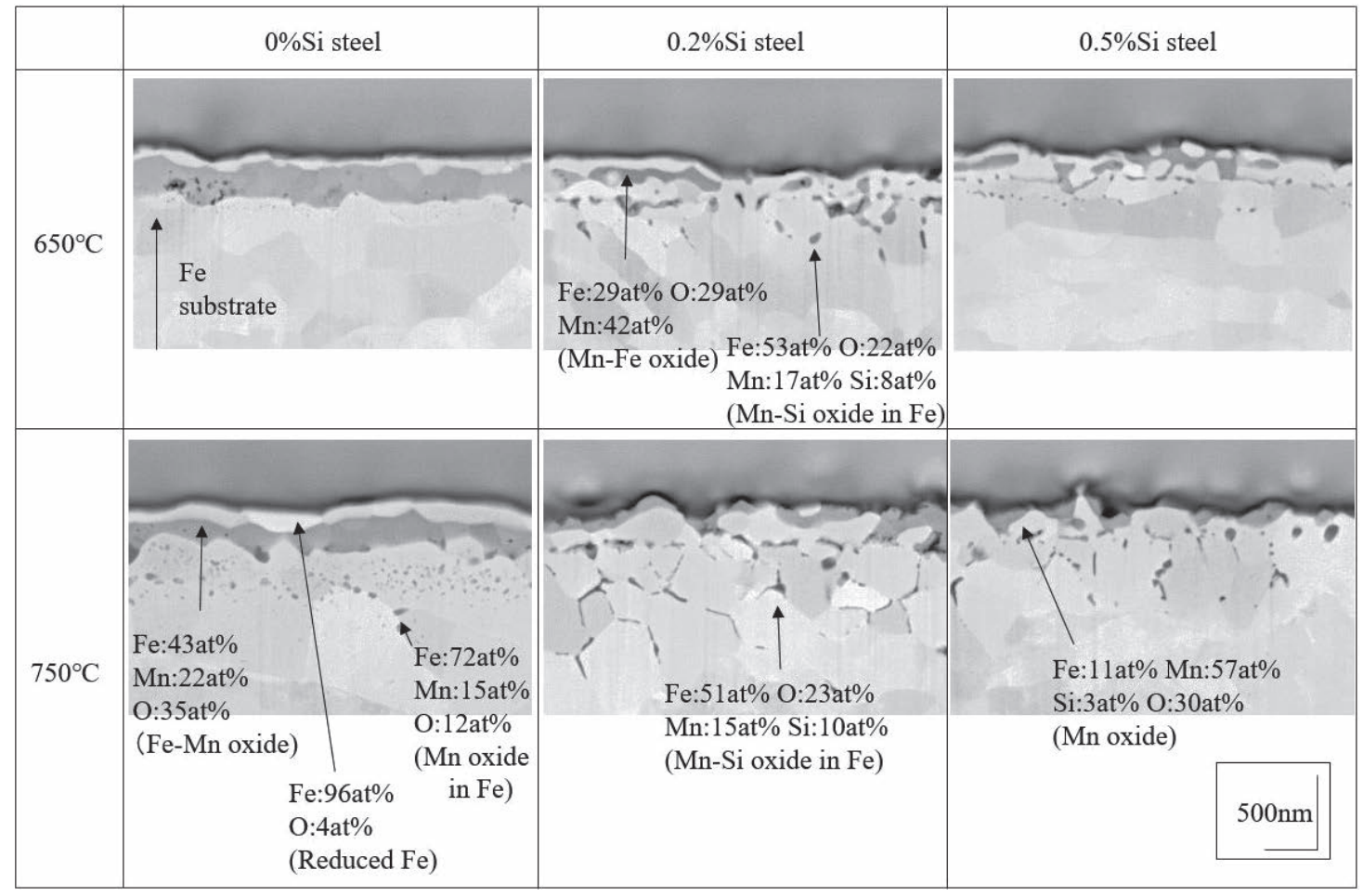

Fig. 8. BSE images and EDX analysis of cross section of each Si-added steel annealed at $650^{\circ} \mathrm{C}$ and $750{ }^{\circ} \mathrm{C}$ with approximately $0.4 \mathrm{~g} \cdot \mathrm{m}^{-2}$ as $\mathrm{O}$ Fe oxide. 
ISIJ International, Vol. 60 (2020), No. 4

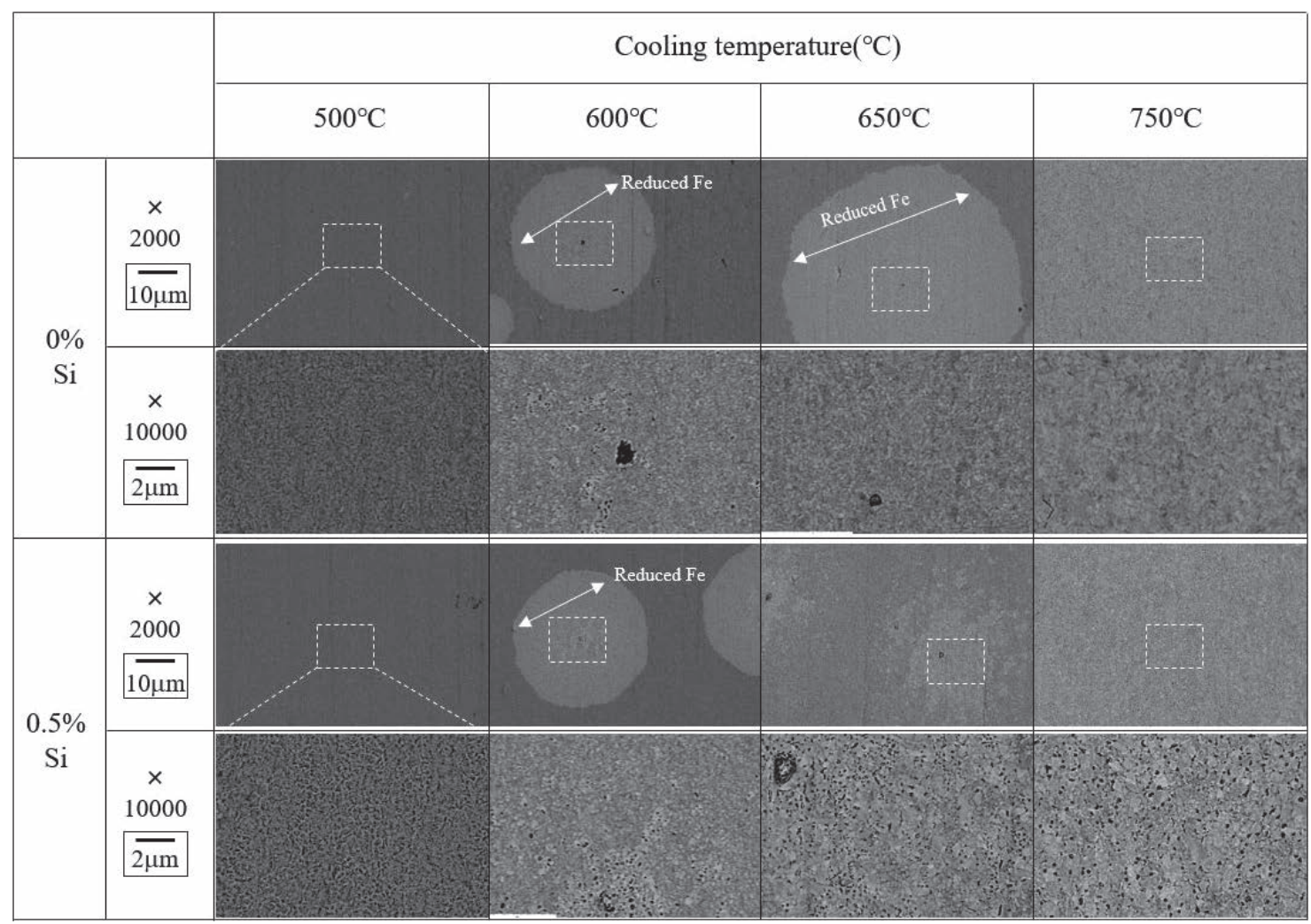

Fig. 10. BSE images of the surface of $0 \% \mathrm{Si}$ and $0.5 \% \mathrm{Si}$ steels at each stage of $\mathrm{Fe}$ oxide reduction.

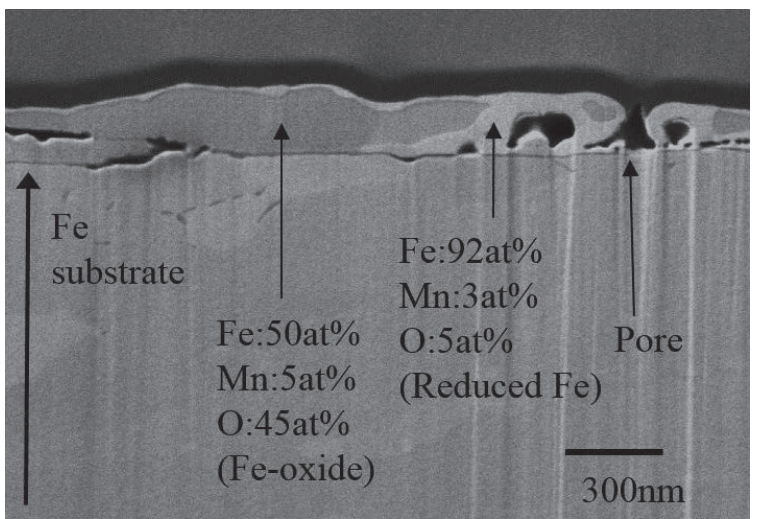

Fig. 11. The SEM image and EDX analysis of initial reduction of Fe oxide near the pore $(0.5 \% \mathrm{Si}$ steel, cooling temperature: $\left.600^{\circ} \mathrm{C}\right)$.

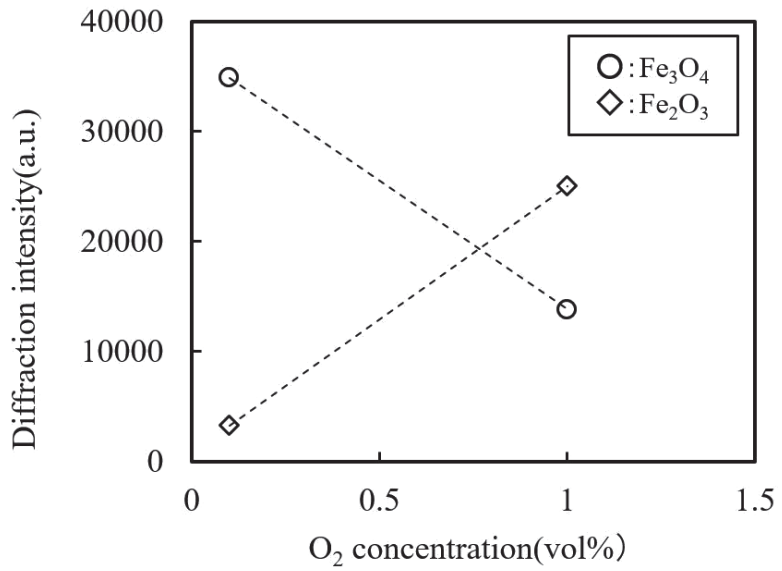

Fig. 12. Influence of $\mathrm{O}_{2}$ concentration of $\mathrm{Fe}$ oxidation on diffraction intensity of $\mathrm{Fe}$ oxide of $0.5 \% \mathrm{Si}$ steel oxidized at $600^{\circ} \mathrm{C}$.

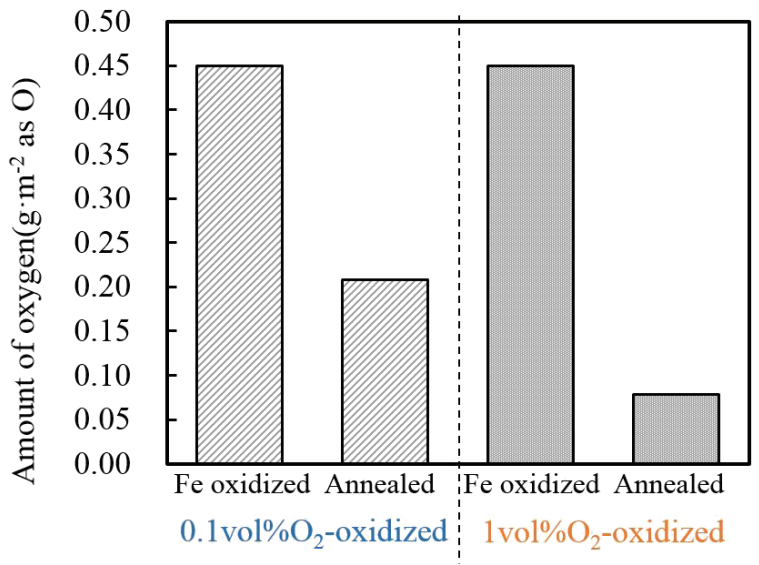

Fig. 13. Influence of $\mathrm{O}_{2}$ concentration of $\mathrm{Fe}$ oxidation on decreasing the amount of Fe oxide of $0.5 \% \mathrm{Si}$ steel at annealing of $650^{\circ} \mathrm{C}$. (Online version in color.)

\section{Discussion}

\subsection{Reduction of Fe Oxide by Internal Oxidation}

$\mathrm{Si}$ addition accelerated the reduction of the Fe oxide, which will be discussed based on the change in behavior accompanying Si addition. Figure 8 showed that the amount and composition of internal oxidation with $\mathrm{Si}$ addition. Table 1 summarizes the internal oxidation behavior of each Si steel. In the following, reduction of the Fe oxide by internal oxidation will be discussed based on equilibrium thermodynamics.

Although the chemical compositions of the internal oxides were not identified in this experiment, based on past studies ${ }^{14-16)}$ investigating the internal oxides of Si- and Mn-added steels, we assumed that the four internal oxides 
shown below were produced by the following equations.

$$
\begin{array}{r}
\underline{\mathrm{Si}}+\mathrm{O}_{2}=\mathrm{SiO}_{2} \\
2 \underline{\mathrm{Mn}}+\mathrm{O}_{2}=2 \mathrm{MnO} \\
2 / 3 \underline{\mathrm{Mn}}+2 / 3 \underline{\mathrm{Si}}+\mathrm{O}_{2}=2 / 3 \mathrm{MnSiO}_{3} \\
\underline{\mathrm{Mn}}+1 / 2 \underline{\mathrm{Si}}+\mathrm{O}_{2}=1 / 2 \mathrm{Mn}_{2} \mathrm{SiO}_{4} \ldots
\end{array}
$$

The equilibrium $\mathrm{O}_{2}$ partial pressure of each reaction was calculated from the free energy change $\Delta \mathrm{G}^{\circ 17,18)}$ of the respective reactions. The activity of $\mathrm{Mn}$ and $\mathrm{Si}$ was assumed to be equal to the atomic concentration. Figure 14 $4^{17)}$ shows the temperature dependency of the equilibrium $\mathrm{O}_{2}$ partial pressure of each oxide. According to Fig. 14, the $\mathrm{O}_{2}$ partial pressure of $\mathrm{Fe}$ oxide is higher than those of $\mathrm{SiO}_{2}, \mathrm{Mn}_{2} \mathrm{SiO}_{4}$, $\mathrm{MnSiO}_{3}$ and $\mathrm{MnO}$ at $650-750^{\circ} \mathrm{C}$. Therefore, reduction of the $\mathrm{Fe}$ oxide by formation of internal oxides containing $\mathrm{Si}$ and $\mathrm{Mn}$ is possible. In addition, the $\mathrm{O}_{2}$ partial pressures of $\mathrm{MnSiO}_{3}$ and $\mathrm{Mn}_{2} \mathrm{SiO}_{4}$ are also lower than that of $\mathrm{MnO}$. This means that $\mathrm{MnSiO}_{3}$ and $\mathrm{Mn}_{2} \mathrm{SiO}_{4}$ can form under a lower $\mathrm{O}_{2}$ partial pressure than $\mathrm{MnO}$, resulting in a thicker internal oxide layer in Si-added steel, as shown in Fig. 8. This formation of internal oxides may accelerate the reduction of the $\mathrm{Fe}$ oxide in Si-added steels.

The maximum reduction amount of the Fe oxide by internal oxidation is equal to the $\mathrm{O}_{2}$ consumption by the internal oxidation reaction. Here, internal oxidation of solute $\mathrm{Si}$ is a concern because $\mathrm{Si}$ addition increases internal oxidation.

Table 1. Characteristics of internal oxide of each Si steel.

\begin{tabular}{lcccc}
\hline & \multicolumn{4}{c}{ Annealing temperature $\left({ }^{\circ} \mathrm{C}\right)$} \\
\cline { 2 - 5 } & \multicolumn{2}{c}{650} & \multicolumn{2}{c}{750} \\
\cline { 2 - 5 } & type & Depth $(\mu \mathrm{m})$ & type & depth $(\mu \mathrm{m})$ \\
\hline $0 \% \mathrm{Si}$ & \multicolumn{2}{c}{ No oxide } & $\mathrm{Mn}$ & 0.3 \\
$0.2 \% \mathrm{Si}$ & $\mathrm{Si}, \mathrm{Mn}$ & 0.3 & $\mathrm{Si}, \mathrm{Mn}$ & 0.8 \\
$0.5 \% \mathrm{Si}$ & $\mathrm{Si}, \mathrm{Mn}$ & 0.3 & $\mathrm{Si}, \mathrm{Mn}$ & 0.5 \\
\hline
\end{tabular}

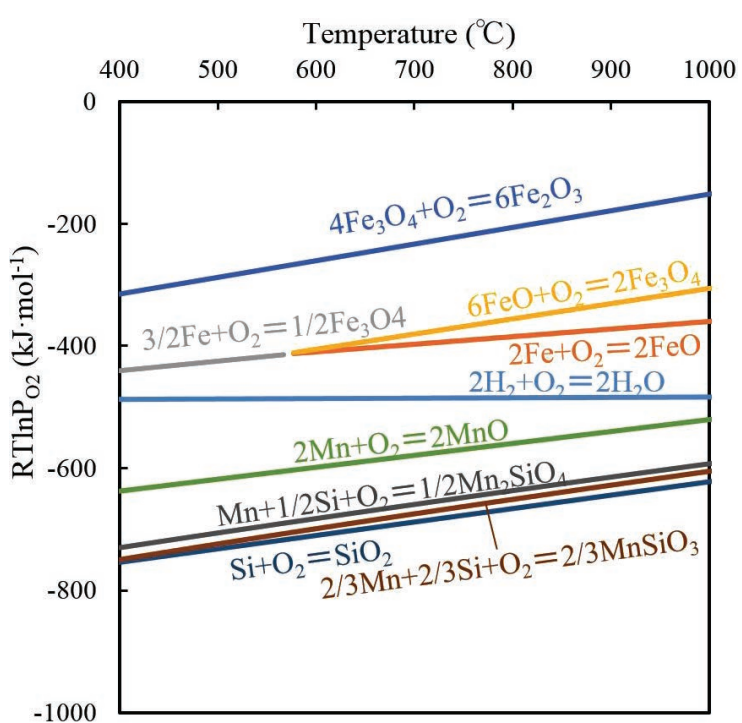

Fig. 14. Equilibrium oxygen partial pressure of Fe, Si, Mn and $\mathrm{Si}-\mathrm{Mn}$ complex oxides. (Online version in color.)
From Eqs. (2), (3) and (4), the $\mathrm{O}_{2}$ consumption when $1 \mathrm{~mol}$ of solute $\mathrm{Si}$ is oxidized to $\mathrm{SiO}_{2}, \mathrm{MnSiO}_{3}$ and $\mathrm{Mn}_{2} \mathrm{SiO}_{4}$ can be calculated as $1 \mathrm{~mol}, 1.5 \mathrm{~mol}$ and $2 \mathrm{~mol}$, respectively. This means that the largest amount of $\mathrm{Fe}$ oxide reduction occurs in the case of $\mathrm{Mn}_{2} \mathrm{SiO}_{4}$ formation. Therefore, in this discussion, the reduction amount was calculated assuming $\mathrm{Mn}_{2} \mathrm{SiO}_{4}$ formation in the $0.2 \% \mathrm{Si}$ steel in order to estimate the maximum reduction amount by internal oxidation. The reduction amount per unit area $\left(\mathrm{X} \mathrm{g} \cdot \mathrm{m}^{-2}\right.$ as $\left.\mathrm{O}\right)$ by oxidation of solute $\mathrm{Si}$ into $\mathrm{Mn}_{2} \mathrm{SiO}_{4}$ in a unit volume $\left(1 \mathrm{~m}^{3}\right)$ is calculated by the following equation.

$$
\mathrm{X}=\mathrm{N} \times \rho_{\mathrm{Fe}} \times \mathrm{C}_{\mathrm{Si}} \times \frac{\mathrm{O}_{2}}{\mathrm{Si}}
$$

$N$ : Molar fraction of $\mathrm{Si}$ and $\mathrm{O}_{2}$ in internal oxidation reaction $(2$ - )

$\rho_{F e}$ : Density of Fe $\left(7.8 \times 10^{6} \mathrm{~g} \cdot \mathrm{m}^{-3}\right)$

$C_{S i}$ : Si mass concentration in steel $(0.2$ mass\%)

$\mathrm{Si}$ : Atomic weight of $\mathrm{Si}\left(28 \mathrm{~g} \cdot \mathrm{mol}^{-1}\right)$

$\mathrm{O}_{2}$ : Molecular weight of $\mathrm{O}_{2}\left(32 \mathrm{~g} \cdot \mathrm{mol}^{-1}\right)$

From Fig. 8, the depth of internal oxidation of the $0.2 \%$ Si steel was approximately $1.0 \mu \mathrm{m}$ from the steel surface. Accordingly, the reduction amount of Fe oxide by solute $\mathrm{Si}$ in a volume of $1 \mathrm{~m}^{2} \times 1 \mu \mathrm{m}$ is calculated as $3.6 \times$ $10^{-2} \mathrm{~g} \cdot \mathrm{m}^{-2}$ as $\mathrm{O}$. This value is much smaller than the oxidation amount of $3.5 \times 10^{-1} \mathrm{~g} \cdot \mathrm{m}^{-2}$ as $\mathrm{O}$. Therefore, reduction of the Fe oxide by internal oxidation is one cause of acceleration of the reduction of the $\mathrm{Fe}$ oxide, but its contribution is small.

\subsection{Effect of $\mathbf{F e}$ Oxide Composition on $\mathbf{H}_{\mathbf{2}}$ Reduction}

As shown in Fig. 9, the reduction amounts in the $0.2 \%$ and $0.5 \% \mathrm{Si}$ steel are 2 to 2.5 times larger than that in the $0 \% \mathrm{Si}$ steel. Since this value represents the decrease of $\mathrm{O}$ in the steel during reduction annealing, a larger amount of $\mathrm{Fe}$ oxide was reduced by $\mathrm{H}_{2}$ in the Si-added steel than in the Si-less steel. As shown in Figs. 7, 10 and 11, Si addition changed the morphology of the reduced Fe. Specifically, the reduced $\mathrm{Fe}$ in the Si-less steel has a solid morphology, whereas the reduced $\mathrm{Fe}$ in the $\mathrm{Si}$-added steel is porous. In the reduction process, contact between $\mathrm{H}_{2}$ and the Fe oxide is limited when the Fe oxide surface is covered with a layer of solid reduced $\mathrm{Fe}$, as in the $0 \% \mathrm{Si}$ steel, and this delays the $\mathrm{Fe}$ oxide reduction by $\mathrm{H}_{2}$. In contrast, the porous morphology of the reduced $\mathrm{Fe}$ in the Si-added steel does not display this barrier effect. Therefore, it can be inferred that this difference in morphology is responsible for the change in the reduction rate of the Fe oxide. It can also be conjectured that the reduced Fe layer is porous in the Si-added steel, but not in the Si-free steel, due to some change in the Fe oxide composition associated with $\mathrm{Si}$ addition. Figure 4 showed that $\mathrm{Si}$ addition increased the content of $\mathrm{Fe}_{2} \mathrm{O}_{3}$ while decreasing the content of $\mathrm{FeO}$. A similar change due to $\mathrm{Si}$ addition has also been reported elsewhere, ${ }^{6,19,20)}$ and is thought to be due to the following mechanism: Because $\mathrm{Si}$ can be oxidized under a low $\mathrm{O}_{2}$ potential, $\mathrm{Si}$ is oxidized preferentially and forms $\mathrm{Si}$ oxides between the $\mathrm{Fe}$ substrate and the $\mathrm{Fe}$ oxide in the oxidation process. This $\mathrm{Si}$ oxide layer suppresses outward diffusion of $\mathrm{Fe}$, resulting in a relative increases in the $\mathrm{O}_{2}$ concentration at the steel surface, which increases the oxidation number of the $\mathrm{Fe}$ oxide. In this experiment, segregation 
of $\mathrm{Si}$ and $\mathrm{O}$ was detected between the $\mathrm{Fe}$ substrate and $\mathrm{Fe}$ oxide, as shown in Fig. 5. Regarding the effect of the $\mathrm{Fe}$ oxide composition on the reduction of the Fe oxide, Fig. 13 shows that an increase of $\mathrm{Fe}_{2} \mathrm{O}_{3}$ in the $\mathrm{Fe}$ oxide increases the reduction rate. This is consistent with the experimental results that $\mathrm{Si}$ addition increased $\mathrm{Fe}_{2} \mathrm{O}_{3}$ and reduction of $\mathrm{Fe}$ oxide was accelerated in the $\mathrm{Si}$-added steel.

Although very few reports concerning reduction of the $\mathrm{Fe}$ oxide on the steel surface have been published, ${ }^{21,22)}$ many reports have examined hydrogen reduction of $\mathrm{Fe}$ oxides used to simulate iron ore. For example, in $\mathrm{FeO}$ reduction, when a dense layer of solid reduced Fe covered the $\mathrm{FeO}$ surface, Tokuda et $a .^{23)}$ reported that the reaction was limited by $\mathrm{O}$ diffusion in the dense reduced $\mathrm{Fe}$, and as a result, reduction was delayed.

One cause of the change in the morphology of the reduced $\mathrm{Fe}$ by $\mathrm{Si}$ addition is presumably the difference in volume contraction caused by the difference in the compositions of the various Fe oxides. Therefore, the proportion of volume contraction was calculated from the density and crystal structure of $\mathrm{Fe}$ and $\mathrm{Fe}$ oxides. $\mathrm{Fe}, \mathrm{Fe}_{2} \mathrm{O}_{3}$ and $\mathrm{Fe}_{3} \mathrm{O}_{4}$ are assumed to be perfect crystals, and $\mathrm{FeO}$ is assumed to be $\mathrm{Fe}_{0.95} \mathrm{O}$ because $\mathrm{FeO}$ generally has lattice vacancy. ${ }^{24,25)}$ Table 2 shows the calculation results, together with the crystal structure $^{26)}$ and density ${ }^{27)}$ of each Fe oxide. The volume contraction from $\mathrm{Fe}$ oxide to metallic $\mathrm{Fe}$ is largest in the case of $\mathrm{Fe}_{2} \mathrm{O}_{3}$, followed by $\mathrm{Fe}_{3} \mathrm{O}_{4}$ and $\mathrm{FeO}$ in that order. Thus, in comparison with $\mathrm{FeO}, \mathrm{Fe}_{2} \mathrm{O}_{3}$ forms a porous substance more readily when reduced, which is consistent with the results of this research shown in Fig. 4 and Figs. 7 to 9. That is, because the proportion of $\mathrm{FeO}$ in the Si-less steel is large, the volume contraction in the reduction process is small, and as a result, the reduced Fe has a solid morphology. On the other hand, owing to the large proportions of
$\mathrm{Fe}_{2} \mathrm{O}_{3}$ and $\mathrm{Fe}_{3} \mathrm{O}_{4}$ in the $\mathrm{Si}$-added steels, volume contraction is also large, and the reduced Fe is porous. D. H. St. John et $a l{ }^{28)}$ investigated the effect of lattice vacancy concentration on the reduction behavior of $\mathrm{FeO}$ and reported that reduced Fe had a larger number of pores in $\mathrm{Fe}_{0.9} \mathrm{O}$ than in $\mathrm{Fe}_{0.95} \mathrm{O}$. This experimental result also showed that an increase in volume contraction changes the morphology of reduced $\mathrm{Fe}$, resulting in a more porous morphology, and is consistent with the tendency observed in the present study.

Figures 12 and 13 showed that $\mathrm{Fe}_{2} \mathrm{O}_{3}$ is reduced more rapidly than $\mathrm{Fe}_{3} \mathrm{O}_{4}$, but since the volume contraction during reduction of $\mathrm{Fe}_{2} \mathrm{O}_{3}$ and $\mathrm{Fe}_{3} \mathrm{O}_{4}$ is $52 \%$ and $53 \%$, respectively, the difference between the two is minimal. This implies that some other cause must be responsible for acceleration of the reduction of $\mathrm{Fe}_{2} \mathrm{O}_{3}$. Generally, the following reactions proceed sequentially in $\mathrm{Fe}$ oxide reduction at temperatures exceeding $570^{\circ} \mathrm{C}$.

$$
\begin{aligned}
3 \mathrm{Fe}_{2} \mathrm{O}_{3}+\mathrm{H}_{2} & =2 \mathrm{Fe}_{3} \mathrm{O}_{4}+\mathrm{H}_{2} \mathrm{O} \\
\mathrm{Fe}_{3} \mathrm{O}_{4}+\mathrm{H}_{2} & =3 \mathrm{FeO}+\mathrm{H}_{2} \mathrm{O} \\
\mathrm{FeO} & +\mathrm{H}_{2}=\mathrm{Fe}+\mathrm{H}_{2} \mathrm{O}
\end{aligned}
$$

Compared to reduction of $\mathrm{Fe}_{2} \mathrm{O}_{3}$, reduction of $\mathrm{Fe}_{3} \mathrm{O}_{4}$ seems to proceed more quickly because $\mathrm{Fe}_{3} \mathrm{O}_{4}$ can be reduced to $\mathrm{Fe}$ in a smaller number of reactions. However, Fig. 13 showed that $\mathrm{Fe}_{2} \mathrm{O}_{3}$ was reduced more rapidly than $\mathrm{Fe}_{3} \mathrm{O}_{4}$. This may be attributable to a change in the lattice structure during reduction. Specifically, the lattice structure of $\mathrm{Fe}_{2} \mathrm{O}_{3}$ is a hexagonal close-packed structure, while the lattice structures of $\mathrm{Fe}_{3} \mathrm{O}_{4}$ and $\mathrm{FeO}$ are cubic close-packed structures, as shown in Table 2. Therefore, when $\mathrm{Fe}_{2} \mathrm{O}_{3}$ is reduced, the lattice structure must be changed through reaction (6), which may cause lattice defects in the reduced $\mathrm{Fe}_{3} \mathrm{O}_{4}$. Assuming

Table 2. Density, structure and volume reduction rate through reduction to $\mathrm{Fe}$ of each Fe oxide.

\begin{tabular}{cccccc}
\hline & Density & Crystal structure & Oxygen coordination & Fe mass per unit volume & $\begin{array}{c}\text { Volume reduction rate } \\
\text { through reduction to Fe }\end{array}$ \\
\hline unit & $\mathrm{g} \cdot \mathrm{cm}^{-3}$ & & & $\mathrm{~g} \cdot \mathrm{cm}^{-3}$ & $\%$ \\
$\alpha-\mathrm{Fe}$ & 7.84 & Body-centered cubic & - & 7.84 & - \\
$\mathrm{Fe}_{0.95} \mathrm{O}$ & 5.74 & Sodium chloride type & Cubic & 4.41 & 44 \\
$\mathrm{Fe}_{3} \mathrm{O}_{4}$ & 5.20 & Inverse spinel & Cubic & 3.76 & 52 \\
$\mathrm{Fe}_{2} \mathrm{O}_{3}$ & 5.26 & Corundum & Hexagonal & 3.68 & 53 \\
\hline
\end{tabular}

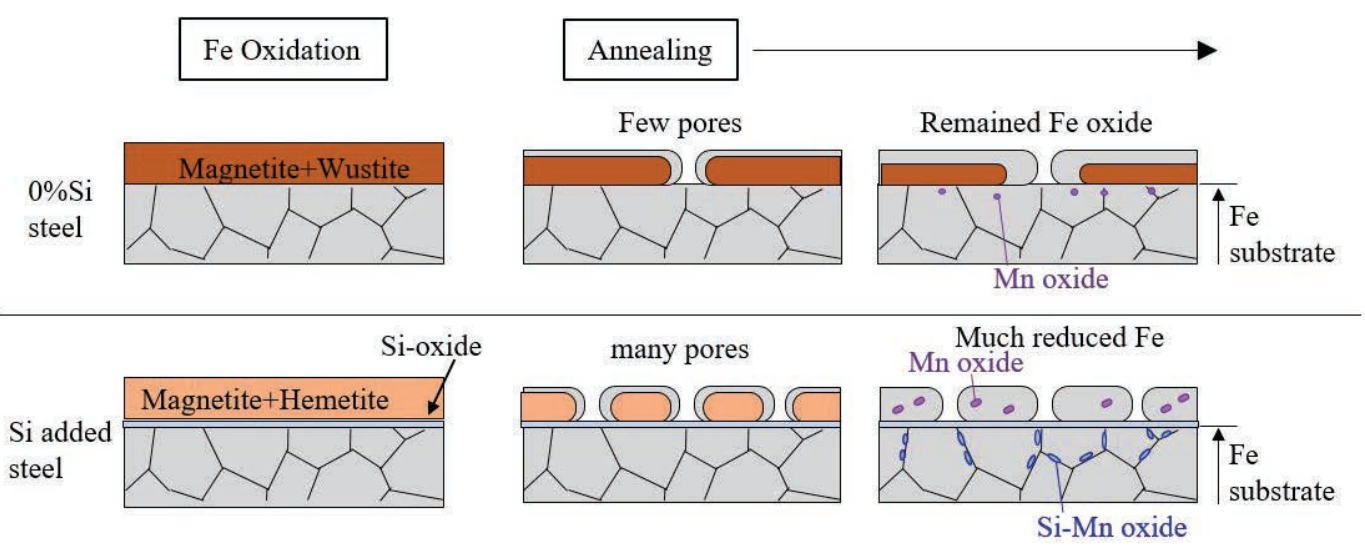

Fig. 15. Schematic images of Fe-oxide reduction in $0 \% \mathrm{Si}$ and $\mathrm{Si}$-added steels. (Online version in color.) 
this kind of defect can accelerate $\mathrm{O}$ diffusion and increase the porosity of the reduced $\mathrm{Fe}$, reduction would be accelerated. On the other hand, since both $\mathrm{Fe}_{3} \mathrm{O}_{4}$ and $\mathrm{FeO}$ have cubic close-packed structures, the crystal structure does not change in reaction (7), hence lattice defects cannot be introduced. In this connection, J. O. Edstrom et al. ${ }^{29)}$ also reported that the reduction rate of $\mathrm{Fe}_{2} \mathrm{O}_{3}$ is faster than that of $\mathrm{Fe}_{3} \mathrm{O}_{4}$.

From this discussion, we concluded that the effect of $\mathrm{Si}$ addition on Fe oxide reduction is as shown in Fig. 15. Si addition changes the composition of the Fe oxide, increasing the proportion of $\mathrm{Fe}_{2} \mathrm{O}_{3}$, while decreasing the proportions of $\mathrm{Fe}_{3} \mathrm{O}_{4}$ and $\mathrm{FeO}$. These changes increase the number of pores in the reduced $\mathrm{Fe}$ and lattice defects in the $\mathrm{Fe}$ oxide, and this has the effect of accelerating Fe oxide reduction by $\mathrm{H}_{2}$.

\section{Conclusion}

The effect of Si addition on the reduction behavior of Fe oxide in annealing of 5.2 mass $\% \mathrm{Mn}$ steel in a $\mathrm{H}_{2}$ atmosphere was investigated. As a result, the following points were clarified.

(1) In Si-less steel, a layer of Fe oxide remained on the steel surface after annealing at $750^{\circ} \mathrm{C}$, but in Si-added steel, virtually all $\mathrm{Fe}$ oxide was reduced. The morphology of the reduced Fe was solid in the Si-less steel and porous in the Si-added steel.

(2) Si addition changed the composition of the internal oxide from a Mn oxide to an $\mathrm{Si}-\mathrm{Mn}$ complex oxide, and as a result, the amount of internal oxidation increased. Although this change accelerated the reduction of the Fe oxide, the amount of Fe oxide reduction by internal oxidation was negligibly small.

(3) $\mathrm{Si}$ addition also changed the composition of the $\mathrm{Fe}$ oxide, resulting in an increase in $\mathrm{Fe}_{2} \mathrm{O}_{3}$ and decreases in $\mathrm{Fe}_{3} \mathrm{O}_{4}$ and $\mathrm{FeO}$. These changes increase the porosity of the reduced $\mathrm{Fe}$ and the number of lattice defects in the $\mathrm{Fe}$ oxide, and this has the effect of accelerating Fe oxide reduction by $\mathrm{H}_{2}$.

\section{REFERENCES}

1) Ministry of the Environment, Government of Japan, General Environment Policy Bureau, Environment and Economic Division: Trends in Fuel Efficiency Standards for Automobiles in Foreign Countries, https://www.env.go.jp/policy/tax/misc_jokyo/attach/trend. pdf, (accessed 2018-07-30) (in Japanese).

2) K. Saito: Materia Jpn., 53 (2014), 584 (in Japanese)

3) M. Sakurai, M. Morita, J. Inagaki and M. Yamashita: CAMP-ISIJ, 8 (1996), 513 (in Japanese).

4) Y. Takada, S. Shimada, J. Lee, M. Kurosaki and T. Tanaka: Tetsuto-Hagané, 93 (2007), 532 (in Japanese).

5) A. Komatsu, S. Andoh and T. Kittaka: Nisshin Steel Tech. Rep., 77 (1998), 1 (in Japanese).

6) M. Miyata, Y. Suzuki, Y. Nagataki and Y. Sugimoto: Tetsu-toHagané, 99 (2013), 214 (in Japanese).

7) T. Nakamura and M. Sato: Tetsu-to-Hagané, 79 (1993), 597 (in Japanese).

8) N. Shigematsu and H. Iwai: Tetsu-to-Hagané, 73 (1987), 1329 (in Japanese).

9) Y. Matsushita and M. Tokuda: Tetsu-to-Hagané, 51 (1965), 651 (in Japanese).

10) H. Natsumeda, A. Kitahara and S. Hashimoto: Tetsu-to-Hagané, 102 (2016), 525 (in Japanese).

11) H. Luo, J. Shi, C. Wang, W. Cao, X. Sun and H. Dong: Acta Mater., 59 (2011), 4002.

12) C. Zhao, C. Zhang, W. Cao, Z. Yang and Y. Weng: Metall. Mater. Trans. A, 46 (2015), 3789.

13) H. Yasuhara and C. Miyagi: JFE Tech. Rep., 13 (2006), 29 (in Japanese).

14) Y. Hirose, H. Togawa and J. Sumiya: Tetsu-to-Hagané, 68 (1982), 2551 (in Japanese).

15) Y. Fushiwaki, Y. Nagataki, H. Nagano, W. Tanimoto and Y. Sugimoto: Tetsu-to-Hagané, 99 (2013), 221 (in Japanese).

16) Y. Makimizu, Y. Suzuki, W. Tanimoto, T. Aoyama and N. Yoshimi: Tetsu-to-Hagané, 102 (2016), 583 (in Japanese).

17) M. Otani: Metallurgical Thermodynamics, Nikkan Kogyo Shimbun, Tokyo, (1971), 207 (in Japanese).

18) J.-H. Huang and E. Rosén: Phys. Chem. Miner., 21 (1994), 228.

19) T. Nakamura and M. Sato: Tetsu-to-Hagané, 79 (1993), 597 (in Japanese).

20) K. Yanagihara and S. Suzuki: Materia Jpn., 39 (2000), 450 (in Japanese).

21) K. Saeki, K. Ikeda, K. Ohno, T. Sato and S. Kurosawa: Tetsu-toHagané, 97 (2011), 12 (in Japanese).

22) O. H. Gellner and F. D. Richardson: Nature, 168 (1951), 23.

23) M. Tokuda, H. Yoshikoshi and M. Ohtani: Tetsu-to-Hagané, 56 (1970), 1899 (in Japanese).

24) S. Nagakura, H. Inokuchi, H. Ezawa, H. Iwamura, F. Sato and R. Kubo: Dictionary of Physics and Chemistry, 5th ed., Iwanami Shoten, Tokyo, (1998), 260 (in Japanese).

25) H. Tanei and Y. Kondo: Nippon Steel Sumitomo Met. Tech. Rep., 401 (2015), 91 (in Japanese).

26) K. Narita: Tetsu-to-Hagané, 53 (1967), 1024 (in Japanese).

27) Handbook of Recent Oxides, ed. by G. Samsonov, Trans. by K. Endo, Nisso Tsushinsha, Wakayama, (1979), 25 (in Japanese).

28) D. H. St. John and P. C. Hayes: Metall. Trans. B, 13 (1982), 117.

29) J. O. Edstrom: J. Iron Steel Inst., 175 (1953), 289. 